\title{
Tornádo 2021 v České republice - psychosociální pomoc IZS v zasažených oblastech
}

\author{
Simona Hoskovcová, Martina Wolf Čapková, Štěpán Vymětal
}

\begin{abstract}
Abstrakt
Tornádo zasáhlo území několika obcí na jižní Moravě ve večerních hodinách ve čtvrtek 24. června 2021. Ačkoliv se jednalo o relativně malé území, rozsahem škod šlo o mimořádnou událost nevídaných rozměrů. Velké množství lidí se ocitlo v prrímém ohrožení života svého a svých blízkých. V psychologii nazýváme takovou událost jako potenciálně traumatizující a ze zkušenosti víme, že může mít závažné dopady na lidskou psychiku. Článek má za cíl představit, jak fungoval systém psychosociální krizové pomoci a spolupráce ${ }^{1}$ zajištovaný ze strany Integrovaného záchranného systému ČR, který tvořil jádro psychosociální pomoci $\mathrm{v}$ akutní fázi katastrofy. Je uvedena návaznost na další organizace, které mají svou funkci především ve fázi stabilizace, ve střednědobé a dlouhodobé péči o zasažené osoby. Považujeme také za potřebné zopakovat principy psychosociální pomoci při mimořádných událostech.
\end{abstract}

Klíčová slova: psychosociální pomoc, psychologie krizí a katastrof, první psychická pomoc, krizová intervence, integrovaný záchranný systém

\section{Tornado 2021 in Czech Republic - psychosocial assistance by the Integrated Rescue System} in the affected area

\section{Abstract}

The tornado hit the territory of several municipalities in South Moravia in the evening on Thursday, June 24, 2021. Although it was a relatively small area, the extent of the damage was extraordinary and of unprecedented proportions. Many people found themselves in direct danger of themselves and their loved ones. In psychology, we call such an event potentially traumatic, and we know from experience that it can have serious effects on the human psyche. The article aims to present how the system of psychosocial crisis intervention and psychological first aid provided by the Integrated Rescue System of the Czech Republic worked. This psychosocial assistance in the acute phase of a disaster builds the core of psychosocial help. There is a link to other organizations, which have their function mainly in the stabilization phase, in the medium and long-term care of the affected persons. We also consider it necessary to repeat the principles of psychosocial assistance in emergencies.

Keywords: psychosocial support, crisis and disaster psychology, psychological first aid, crisis intervention, integrated rescue system

\footnotetext{
${ }^{1}$ Pojem a činnosti upravují Standardy psychosociální krizové pomoci a spolupráce zaměřené na prủběh a výsledek a Typová činnost složek IZS při poskytováni psychosociálni pomoci STČ 12/IZS.
} 


\section{Katastrofa - kontext mimořádné události}

Mimořádnost tornáda v červnu 2021 na jižní Moravě byla v náhlosti dopadu a jeho síle srovnatelná napřr. s terorismem, kdy je minimum času k úniku do bezpečí. Vznikly mimořádně velké materiální škody na prostorově limitovaném území a masivní náhlý psychický dopad na místní obyvatelstvo. Situace působila na zasahující interventy jako „znásobené bleskové povodně“, ale i jako „válečná zóna“. V místech byl zároveň vnímán potenciál sousedské pomoci a prirozené komunitní podpory.

Specifickou zátěží pro duševní zdraví populace bylo oslabení v důsledku covid-19. V individuálních prŕípadech šlo o opakovanou traumatizaci - např́klad náhlé úmrtí blízké osoby následkem onemocnění covid19 a později ohrožení života a zásadní materiální ztráta.

Pro takové případy mají složky Integrovaného záchranného systému ČR (dále „IZS“) plán psychosociální pomoci zasaženým osobám pro urgentní fázi neštěstí, jehož cílem je pomoc v prvních chvílích a dnech po události. Tato pomoc má za cíl nastartovat proces zotavení se jedinců a komunity po takto ohrožujícím zážitku.

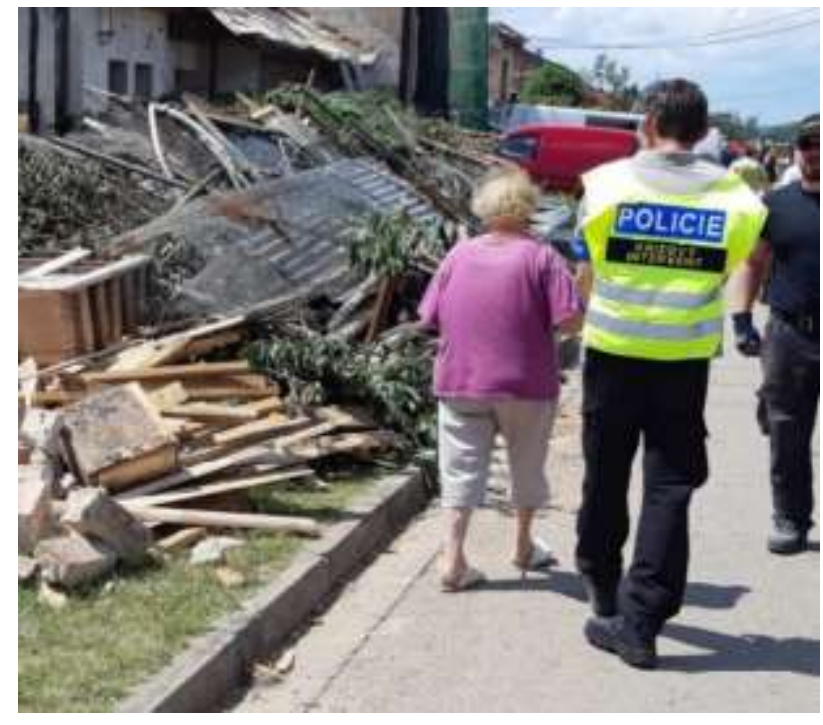

Obrázek 1: Akutni fáze katastrofy. Autor Rostislav Koběrský

Souhra jednotlivých složek při poskytování psychosociální pomoci je regulována typovou činností STČ 12/IZS Typová činnost složek IZS při poskytování psychosociální pomoci. Tato typová činnost určuje, která složka je zodpovědná za koordinaci psychosociální pomoci - v této situaci to byl Hasičský záchranný sbor (dále „HZS“). Typová činnost dále vymezuje okruhy činnosti a zodpovědnost za jednotlivé části psychosociální pomoci. Psychosociální pomoc (dále jen „PSP“) zajištěná př́mo pracovníky IZS je v Evropě i v porovnání se světem unikátní a umožňuje rychlou, odbornou a efektivní pomoc v místě mimořádné události. Měli jsme možnost diskutovat rozdíly $\mathrm{v}$ systému poskytnutých služeb po tornádu na jižní Moravě s kolegou ze SRN, kde v červenci udeřily bleskové a devastující povodně. Kvůli decentralizované organizaci, kdy si různé úrovně pomoci regulují jednotlivé spolkové země, nebyla psychosociální pomoc řádově ve dnech po události zasaženému obyvatelstvu v SRN k dispozici (Stoeck, F., osobní sdělení).

Každá základní složka IZS vČR má své psychology, k jejichž činnosti patří také poskytování krizové intervence občanům při mimořádných událostech. Dále má každá složka vyškolené pracovníky pro poskytování první psychické pomoci či podpory v mimořádně zátěžových situacích zasaženým osobám jak z řad veřejnosti, tak ze svých sborů (PČR má krizové interventy, HZS má členy týmů posttraumatické péče a ZZS má interventy sdružené v organizaci SPIS). Dále má každá složka vyškolené pracovníky, kteří jsou schopni poskytovat kolegiální podporu („,peeři“‘). Ti se zaměřují především dovnitř sborů, kde poskytují kolegům základní péči a dokážou nasměrovat k odborné pomoci. 


\section{Organizace psychosociální pomoci}

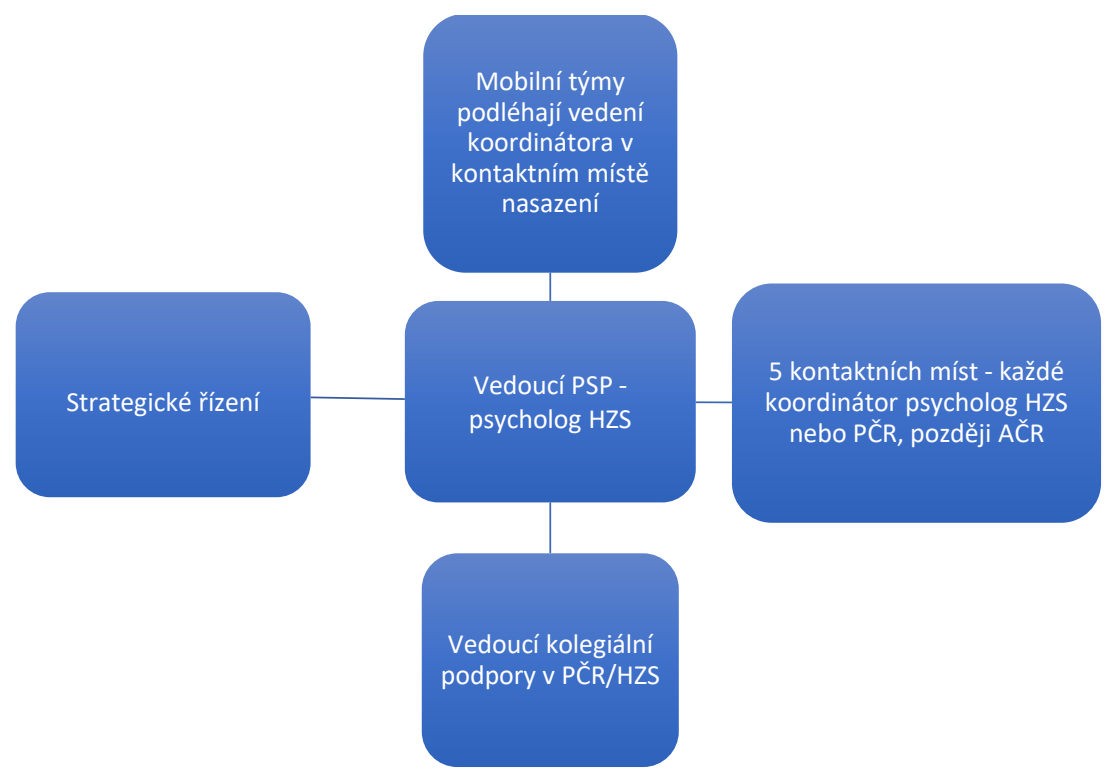

Obrázek 2: Organizace PSP dle Juen, 2021

Pro celkovou koordinaci PSP v zasaženém území byl ustanoven koordinátor PSP IZS, kterým byl v tomto př́ípadě psycholog HZS. Úkolem koordinátora IZS je zejména řídit systém poskytování PSP, rozdělení činností, rozdělení místa působení jednotlivých poskytovatelů PSP, domluva na způsobu předávání informací a v neposlední řadě spolupráce s krizovými štáby. V každé z nejvíce zasažených obcí byl dále vytvořen vlastní tým se svým sektorovým koordinátorem. Oblast byla nejdř́ive rozdělena na 4 sektory (Mikulčice, Lužice, Hrušky a Moravská Nová Ves). Od 27. 6. 2021 byl zř́zen 5. sektor Hodonín-Pánov. Každý sektor měl svého koordinátora, kterým byl psycholog HZS nebo PČR a později Armády České republiky (dále jen „AČR“). V každém sektoru byly smíšené týmy poskytovatelů pomoci - krizoví interventi PČR, členové týmu posttraumatické péče HZS, dobrovolníci Diakonie, Charity a Českého červeného kříže, případně další odborníci. Tyto týmy spolupracovaly v průběhu celé doby se dvěma dvojicemi policistů $\mathrm{z}$ antikonfliktního týmu PČR. Později přibývali dobrovolníci dalších organizací. Týmy PSP byly vysílány i mimo sektory - např. do nemocnice v Hodoníně nebo do hotelu, kde byli ubytovaní senioři z evakuovaného domova pro seniory. Každý tým měl své pevné stanoviště, kde byl stále př́tomen někdo z členů týmu a několik terénních týmů.

Od 30. 6. 2021 byli součástí týmů psychologové z projektu Nepanikař.eu, jedná se o dobrovolnické uskupení prověřených odborníků z praxe. Výhodou tohoto systému je, že organizace Nepanikař.eu organizuje dobrovolníky a posílá je tam, kde jsou potřeba. Bohužel se našla i řada neorganizovaných psychologů, kteří přijeli do oblasti „na vlastní pěst“ a nevěděli o systému poskytování psychosociální pomoci IZS. Někteří zasažení tak byli opakovaně oslovováni s nabídkou psychologické pomoci, přičemž tato přemíra nabídky je až obtěžovala. 
Psychologům, kteří by $\mathrm{v}$ budoucnosti chtěli nabídnout svou dobrovolnickou činnost, doporučujeme, aby se obrátili na některou z velkých neziskových organizací, které se v místech mimořádných událostí podílejí na psychosociální pomoci (Český červený kříž, ADRA, Charita, Diakonie, Člověk v tísni apod.) nebo na koordinátora psychosociální pomoci z příslušné složky IZS (zpravidla psycholog daného bezpečnostního sboru).

Psychosociální pomoc byla složkami IZS poskytována od pátku 25. 6. 2021 do pátku 9. 7.

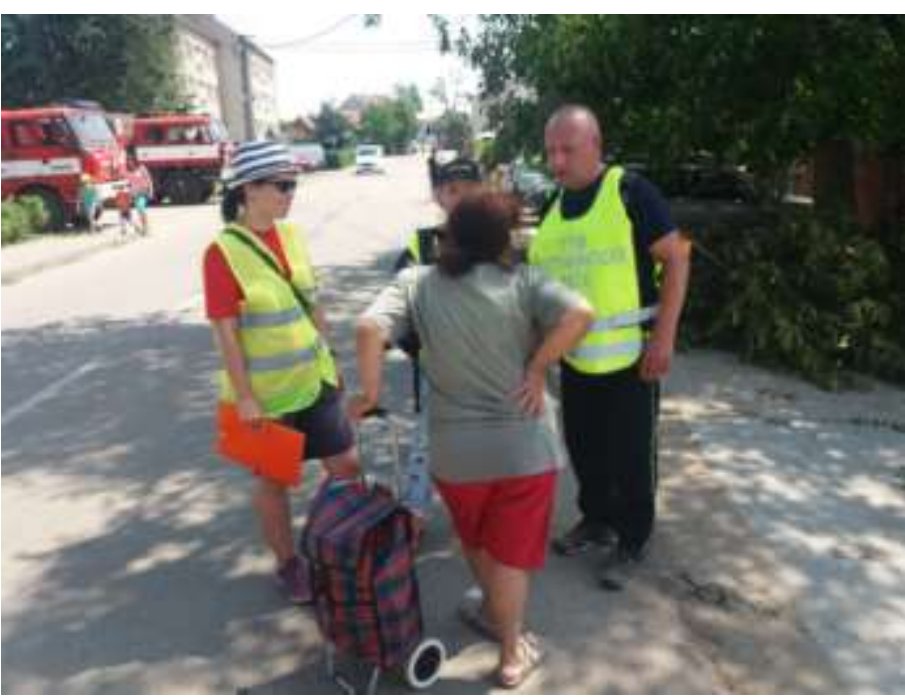
2021, kdy byla její koordinace předána nestátním neziskovým organizacím. V tomto období proběhlo přes 4000 intervencí, z toho asi 400 delších než 30 minut. Pro srovnání uvádíme, že ročně poskytnou jen krizoví interventi PČR průměrně 3000 intervencí. Na výpomoc postupně prrijeli psychologové, krizoví interventi a členové týmu posttraumatické péče (dále jen „TPP“) z celé republiky, což nebývá obvyklé. Uvolňování sil a prostředků proběhlo velmi flexibilně a rychle.

Obrázek 3: Tým PSP složený ze zástupce HZS, PČR a neziskové organizace.

Autor HZS Královéhradeckého kraje

\section{Činnosti PSP IZS v místě}

$\mathrm{Na}$ místě se jednalo o monitoring psychosociálních potřeb, psychosociální triáž (identifikace více zranitelných jedinců/skupin), a v prŕpadě potřeby o první psychickou pomoc a krizovou intervenci. Následovalo zprostředkování humanitární a materiální pomoci a přenos informací pro krizový štáb a pro $\mathrm{MV}$, Generální ředitelství HZS, Policejní prezidium a Ministerstvo zdravotnictví. Specifické nabídky pomoci a psychologické informace byly zaměřeny na klíčové jednotlivce a skupiny (starostové, zastupitelé obcí, sbory dobrovolných hasičů, zdravotnický personál nemocnic Jihomoravského kraje), zvláštní pozornost byla věnována zranitelným skupinám (senioři z dotčeného domova pro seniory, personál domova, pozůstalí, zranění, lidé s disabilitou, osaměle žijící, lidé s předchozím traumatem, děti apod.).

Podpora byla obyvatelům poskytována i v průběhu demolic jejich domů.

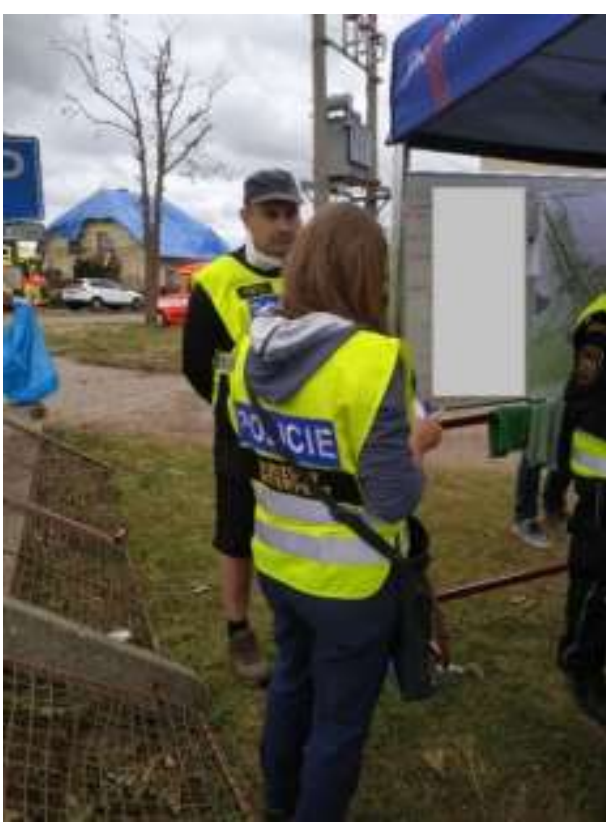

Obrázek 4: Stanoviště PSP. Autorka Jana Takáčová 


\section{Využití systému kolegiální podpory při PSP}

Úkolem psychologů bezpečnostních sborů je zabezpečit také péči o zasažené př́islušníky a zaměstnance. Psychologové, krizoví interventi a členové TPP se v terénu průběžně pouštěli do hovoru s prrítomnými př́slušníky a ptali se na jejich potřeby a prožívání situace. Byli také identifikováni příslušníci osobně zasažení touto mimořádnou událostí, protože na daném území bydlí. Někteří přišli o majetek, a navíc museli vykonávat činnosti v rámci svých služebních povinností. Těmto př́slušníkům byla poskytnuta adekvátní péče. Zasažení kolegové dostali finanční podporu, další formy podpory z Fondu kulturních a sociálních potřeb a byly zmapovány i jejich psychologické potřeby. U př́slušníků vyslaných z jiných krajů ČR jsme zaznamenali zátěž způsobenou např́ílad dlouhou směnou a odjezdem do domovského kraje v jednom dni, vnitřním nesouladem s rolí, kterou tam zastávali (hlídková činnost vs. chut' aktivně pomáhat sodklízením trosek), nejasnou komunikací s velením. Hlubší potíže zaznamenali poskytovatelé kolegiální podpory a psychologové jen velmi ojediněle a tyto osoby směřovali k odborné péči.

\section{Role strategického řízení PSP}

Strategickému řízení PSP se věnovali psychologové, kteří tvoří Pracovní skupinu ministra vnitra pro podporu duševního zdraví populace při mimořádných událostech (dále „PSMVDZ“). Jako hosté byli přizváni zástupci Českého červeného křiže a hlavní garant Systému psychosociální intervenční služby (dále „SPIS“) z rezortu zdravotnictví. Společně bylo koordinováno rozložení sil a prostředků, a také komunikace s dobrovolníky, kteří nabízeli své služby v psychosociální oblasti. Informace a dohodnuté postupy byly předávány zpět do složek IZS. Po události proběhlo u PČR shrnutí poskytované PSP formou debrífinku (psychologická metoda pro zpracování potenciálně traumatizujících zážitků) v týmech systému krizové intervence, které si ho vyžádaly (u HZS proběhlo ošetření nasazených týmů na úrovni jednotlivých HZS krajů). Zároveň proběhl průzkum potřeb a faktorů zátěže a odolnosti u zasahujících interventů, jehož výsledky slouží pro zlepšené praxe a vzdělávání do budoucna.

PSMVDZ se podílela na tvorbě materiálů pro využití $v$ terénu, předávala informace do médií pro veřejnost, informace směrem $\mathrm{k}$ vedení $\mathrm{MV}$ ČR, doplňovala web s informacemi a adresářem pomoci - viz www.mvcr.cz a informace na stránkách www.opatruj.se (spolupracující portál pro podporu duševního zdraví). Využity byly i specifické informace „Virtuálního asistenčního centra HZS“ dostupné na www.tvhasici.cz. Byly předávány informace $\mathrm{k}$ odborné psychologické veřejnosti prostřednictvím webů profesních organizací Unie psychologických asociací ČR a Českomoravské psychologické společnosti. Za zmínku stojí i zajišt'ování informační výměny a spolupráce s kolegy z IZS a neziskových organizací při paralelní mimořádné události na Lounsku, která byla rovněž způsobena extrémním počasím.

\section{Přechod od akutní fáze $k$ následné péči}

Dne 9. 7. 2021 došlo k předání koordinace Ústřednímu krizovému týmu Českého červeného kř́že, který PSP koordinoval do 18. 7. 2021. Dále byla koordinační role předána místní organizaci Spondea. Ta bude nadále koordinovat činnosti v Jihomoravském kraji v rámci střednědobé a dlouhodobé péče. (Na Lounsku od počátku koordinovala činnosti organizace Spirála, zejména místní panel humanitárních a dalších organizací). 
Vnímáme nutnost rozlišovat mezi první psychickou pomocí, krizovou intervencí a podpůrným (či mapujícím) rozhovorem, případně pomocí, která již nespadá do péče psychologů a interventů (např́íklad zajištění léků pro seniory apod.). Obyvatelé zasažených obcí byli podporováni $\mathrm{v}$ samostatnosti a bylo potřeba rozlišit, kdo z nich potřebuje následnou (střednědobou a dlouhodobou) péči. Interventi byli směřováni $\mathrm{k}$ tomu, aby dovedli rozlišovat, kdo může z další odborné pomoci profitovat a kdo ji nepotřebuje či se zotaví s podporou svých blízkých. Tedy aby si systém PSP takzvaně nevyráběl klienty, ale aby dokázal v lidech podpořit vlastní zotavovací mechanismy a detekoval jedince, kteří potřebují odbornou pomoc (jeden z principů PSP dle Hobfolla, 2007).

Společně se zástupci zasažených komunit a neziskovými organizacemi byly určeny jednotlivé oblasti, v nichž bude následná péče poskytována (děti, školy, senioři...). Střednědobá a dlouhodobá péče byla předána do odpovědnosti dalších organizací (Spondea, Modrý Anjel, Český institut pro psychotraumatologii a EMDR), zajištěna $\mathrm{z}$ místních zdrojů (místní psycholožka, PPP apod.) a přes další neziskové organizace. Byl naplánován systém vzdělávání a supervize pro psychology poskytující střednědobou a dlouhodobou péči (zajišt'uje zejména Český institut pro psychotraumatologii a EMDR a Modrý Anjel). Cílem je snaha o co nejkvalitnější a efektivní péči o zasažené. V oblasti se objevovalo také množství různých odborníků na duševní zdraví, kteří nebyli koordinováni. To nebylo v dané situaci žádoucí, protože chyběl celkový přehled o tom, komu byla péče již poskytována a komu ne. U některých se následně zjistilo, že nabízejí své služby bez odpovídajícího vzdělání. Ti, kteří měli odborné vzdělání, byli vyzváni, aby se registrovali do systému (na e-mail ČČK) a bylo jim sděleno, že budou $\mathrm{v}$ prrípadě potřeby osloveni.

Podpora spolkové činnosti jednotlivých obcí podporuje i komunitní odolnost. Proběhly schůzky se starosty jednotlivých obcí, př́ípadně s faráři nebo zástupci obecních spolků. Cílem bylo podpořit činnost spolků $\mathrm{v}$ jednotlivých obcích a návrat $\mathrm{k}$ běžným aktivitám.

\section{Psychologické aspekty mimořádné události}

U lidí, kteří zažili tuto mimořádnou událost, naši interventi viděli v akutní fázi po události jevy, jako je euforie z přežití, odštěpení emocí, akutní stresové reakce. Někteří lidé byli zpočátku v šoku a nevěděli, kde jsou a co se stalo. Méně známé je, že se u mnohých lidí objevuje i pocit viny „,z př̌žití““ nebo „z nezasaženi““. Proto naši interventi obcházeli také části zasažených obcí, kde nikdo materiální škodu neutrpěl, a poskytovali krizovou intervenci potřebným občanům.

Poskytovatelé psychosociální podpory všech systémů IZS sledují jednotné standardy (Standardy, 2010 a STČ12/IZS) a jsou školeni k dodržování základních principů tohoto typu akutní krizové pomoci. Patří sem i představení sebe a své role. V maximální možné míře usilují o zvýšení pocitu bezpečí u zasažených osob, podporují propojení s blízkými a přirozenou sociální sítí. Aktivně oslovují zasažené a naslouchají jim. Zasaženým osobám pomáhá klidné vystupování profesionálů, kteří mají s mimořádnými událostmi zkušenost.

Respektujeme v poskytování PSP pět základních principů podle Hobfolla (2007), tedy podporujeme pocit bezpečí, uklidňujeme, podporujeme vnímanou osobní i komunitní účinnosti (efficacy), posilujeme vzájemné vztahy a udržujeme naději. Poskytovatelé psychosociální podpory vnášejí do chaotické situace strukturu nebo pomáhají strukturu vytvářet. Umožní zasaženým ventilovat emoce a začít racionálně uvažovat. Velmi přispívají k přenosu ověřených informací. Potřeba být informován patří mezi klíčové potřeby a je protilátkou k panice či 
nejistotě. Přijetí nejrůznějších typů stresových reakcí u zasažených osob působí preventivně před stažením se zasažených lidí do ústraní či jejich pocitu odcizenosti. Povzbuzují aktivitu a vzájemnou pomoc, čímž předcházejí pocitu bezmoci (Hausmann, 2003).

První týdny po události pomáhala situaci zvládat silná tzv. heroická fáze. Snaha o obnovu byla tak silná a nabudila fyzické i psychické síly zasažených i dobrovolníků do té míry, že je krizoví interventi upozorňovali na nutnost odpočívat. Často je také doprovázeli k lékaři, protože zasažení nevnímali bolest ze svých zranění. Krizoví interventi a psychologové poskytovali psychosociální podporu souběžně s praktickou pomocí. Pouštěli se do řeči s lidmi, kterým donesli vodu nebo si povídali během úklidu nezničených částí domu. Velké části lidí uleví právě možnost promluvit si o svém prožívání s důvěryhodnou osobou, která je nehodnotí ani nepopírá míru vnímaného prožitku.

Ve druhém týdnu po události vyžadovali psychickou podporu nejen přímo zasažené osoby, ale také dobrovolníci, u kterých se kvůli vyčerpání projevily i některé závažné psychické potíže. Ve sborech IZS máme nastavené postupy, kterými usměrňujeme míru zátěže a předcházíme potížím z vyčerpání. Je to například stř́ídání interventů nebo večerní brífink vyhodnocení a uzavření dne. Psychologický debrífink po skončení akce je metoda, pomocí níž se při skupinovém setkání psychicky zpracují potenciálně traumatizující zážitky členů uniformovaných složek, kteří společně zasahovali. Neorganizovaní dobrovolníci bohužel mnohdy neodhadli své možnosti a síly.

Velkou výhodou dané lokality je to, že komunity v zasažených obcích jsou velmi soudržné a odolné, zakotvené v místě po generace. V takových komunitách velmi dobře funguje sousedská pomoc a aktivní zapojení občanů a jejich blízkých do obnovy obce. Naši krizoví interventi tak např́ílad viděli v jednom domě větší skupinu dětí, které se prrirozeně ujala učitelka místní ZŠ. Jindy potkali skupinu adolescentů, kteří pomáhali, co jim jejich síly stačily. Z psychologického hlediska určitě doporučujeme, aby se i dospívající př̌iměřeně zapojovali do obnovy obce, posiluje to jejich osobní vnímanou účinnost i mezigenerační soudržnost. $\mathrm{V}$ př́ipadě této skupinky interventi viděli únavu a z důvodu odpočinku je nasměrovali na př́ští den do školy, která byla otevřená v jedné z obcí jako zázemí pro děti. Př́kladů vzájemné pomoci bylo samozřjejě více, než se na tyto stránky vejde.

Většina lidí má kapacitu přirozeně se zotavit z mimořádné zkušenosti. Při své činnosti krizoví interventi cíleně vyhledávají zvláště zranitelné skupiny lidí a jednotlivce a ověřují, zda potřebují nějakou formu podpory. Vyhledávali osaměle žijící osoby a osoby s různými typy zdravotního postižení.

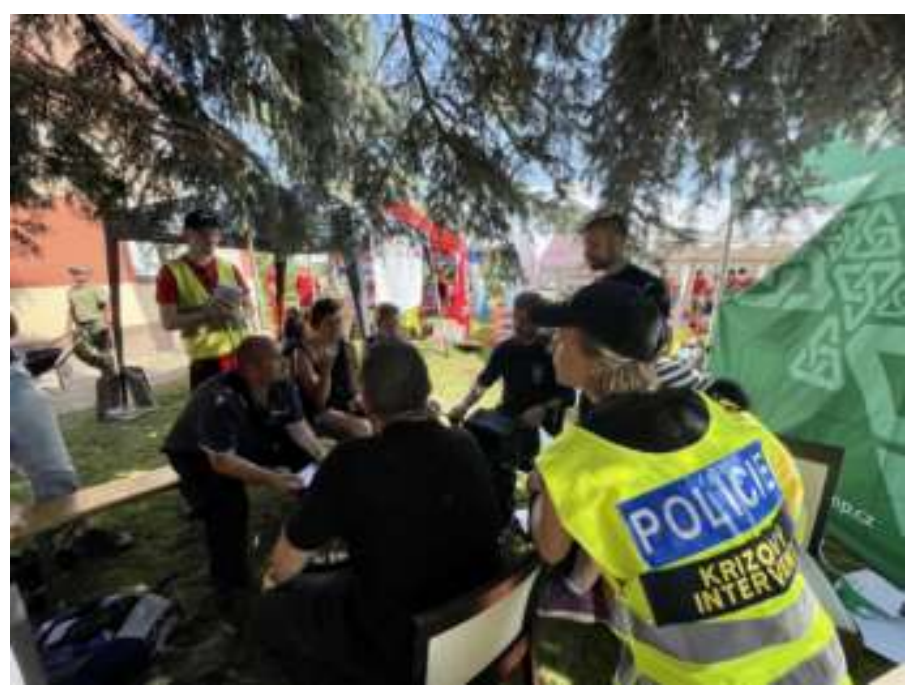

Obrázek 5: Brifink týmu PSP v jednom ze sektorů. Autor HZS Královéhradeckého kraje 
Chodili asistovat i na místa, kde docházelo k nařízeným demo-licím domů. Policii přísluší oznamování o úmrtí při mimo-řádných událostech, a tak i v tomto př́padě poskytovali krizoví interventi PČR oporu pozůstalým.

K hlavním principům krizové intervence patří podpora aktivního přístupu zasažených (čelí tím bezmoci), posilování zvládání a odolnosti, posilování komunitní odolnosti a soudržnosti i dodávání naděje (Hobfoll, 2007). Zasažené ujišt'ujeme, že pokud prožívají stresové reakce jako jsou nespavost, úzkost, vtíravé myšlenky a další, jde o normální reakce na nenormální situaci. Zasažení lidé se často obávají, že se zbláznili a stydí se o svém prožívání mluvit. Pohybujeme se na křehké hranici, protože na druhou stranu zdůrazňujeme sílu většiny se zotavit, a proto mluvíme spíše o tom, co pomáhá než o všech možných projevech traumatu. Důležité totiž je, abychom př́ípadné symptomy lidem nepodsouvali, a naopak podpořili jejich přirozené vnitřní a sociální zdroje opory.

\section{Literatura}

Hausmann, C. (2003). Handbuch Notfallpsychologie und Traumabewältigung: Grundlagen, Interventionen, Versorgungsstandards. facultas. wuv/maudrich.

Hobfoll, S. E., Watson, P., Bell, C. C., Bryant, R. A., Brymer, M. J., Friedman M. J., Friedman, M., Gersons, B. P. R., Jong, J. T.V.M de, Layne, C. M., Maguen, S., Neria, Y., Norwood, A. E., Pynoos, R. S., Reissman, D., Ruzek, J. I., Shalev, A. I., Solomon, Z., Steinberg, A. M., \& Ursano, R. J. (2007). Five essential elements of immediate and midterm mass trauma intervention: Empirical evidence. Psychiatry: Interpersonal and Biological Processes, 70(4), 283-315. https://doi.org/10.1521/psyc.2007.70.4.283

Juen, B. (2021, 3. března). Organisation of psychosocial assistance. [Powerpoint presentation]. Workshop „Head of Operation“, online pro PČR.

Ministerstvo vnitra. GŘ HZS ČR. (2016). Katalog typových činností integrovaného záchranného systému: Typová činnost složek IZS při poskytování psychosociální pomoci STČ 12/IZS. https://www.hzscr.cz/soubor/stc-12-izs-typova-cinnost-slozek-izs-priposkytovani-psychosocialni-pomoci-122015-pdf.aspx

Ministerstvo vnitra. Generální ředitelství Hasičského záchranného sboru ČR. (2010. Standardy psychosociální krizové pomoci a spolupráce zaměřené na průběh a výsledek. https://www.hzscr.cz/soubor/standardy-pskps-prosinec2010-pdf.aspx 


\section{O autorech}

PhDr. Simona Hoskovcová, Ph.D., psycholožka, pracuje jako vedoucí skupiny krizové intervence na Policejním prezídiu ČR. Dlouhodobě se věnuje vývoji psychické odolnosti. Kontakt: simona.hoskovcova@pcr.cz

PhDr. Štěpán Vymětal, Ph.D., psycholog se zaměřením na katastrofy a krizové řízení, zastupuje ČR ve Stálém výboru pro psychologii krizí, katastrof a traumatu EFPA, pracuje jako psycholog MV ČR.

Kontakt: stepan.vymetal@mvcr.cz

plk. Mgr. Martina Wolf Čapková, psycholožka, vykonává pozici vedoucího psychologa a metodika na MV-Generálním ředitelství HZS ČR. Zaměřuje se na psychologii mimořádných událostí a na krizovou intervenci.

Kontakt: martina.capkova@grh.izscr.cz

Hoskovcová, S., Vymětal, Š., \& Wolf Čapková, M. (2021). Tornádo 2021 v České republice psychosociální pomoc IZS v zasažených oblastech. E-psychologie, 15(4), 60-68.

https://doi.org/10.29364/epsy.421 